\title{
Detection of prostate specific ETS fusion transcripts in cancer samples
}

\author{
L. V. Mevs ${ }^{1 *}$, G. V. Gerashchenko ${ }^{1 *}$, E. E. Rosenberg ${ }^{1}$, M. V. Pikul ${ }^{2}$, \\ M. V. Marynychenko ${ }^{2}$, O. P. Gryzodub ${ }^{3}$, S. O. Vozianov' ${ }^{3}$, \\ E. A. Stakhovsky ${ }^{2}$, V. I. Kashuba ${ }^{1}$ \\ * These authors contributed equally to this work \\ ${ }^{1}$ Institute of Molecular Biology and Genetics, NAS of Ukraine \\ 150, Akademika Zabolotnoho Str., Kyiv, Ukraine, 03680 \\ ${ }^{2}$ National Cancer Institute \\ 33/43, Lomonosova Str., Kyiv, Ukraine, 03022 \\ ${ }^{3}$ State Institution «Institute of Urology of NAMS of Ukraine» \\ 9-a, Yu. Kotsubyns'koho Str., Kyiv, Ukraine, 04053 \\ LiliaMevs@meta.ua
}

\begin{abstract}
Aim. To detect ETS fusion transcripts in Ukrainian population and to analyze a possible relationship between the ETS fusion transcripts and clinical characteristics of prostate cancer. Methods. Quantitative PCR (q-PCR) was used to analyze the expression of six fusion transcripts at the mRNA level. The amplified products were analyzed by gel electrophoresis and direct sequencing. We analyzed 37 fresh frozen samples of prostate cancer tissues, 37 paired conventionally normal prostate tissue samples and 20 samples of adenomas. Results. Six ETS fusion transcripts of TMPRSS2 with ERG, ETV1, ETV4, ETV5 were analyzed. Only one out of six fusion ETS transcripts was detected in a cohort of 37 Ukrainian patients with prostate adenocarcinoma. The frequency of detection of the TMPRSS2-ERG fusion transcript in prostate cancer tissues was $56.8 \%$. The TMPRSS2-ERG expression was also detected in 16 normal prostate tissue samples $(43.2 \%)$ and in 4 prostate adenoma samples $(20 \%)$. No correlation was found between the frequency of the TMPRSS2-ERG in carcinoma samples and clinical characteristics of the samples. However, an analysis of relative gene expression in all the investigated groups has shown the altered TMPRSS2-ERG expression in some groups with different Gleason scores of prostate adenocarcinoma compared to adenomas and normal tissue samples. The most elevatedTMPRSS2-ERG expression was found in the prostate adenocarcinoma group with the Gleason score $>7$. Conclusions. We detected the TMPRSS2-ERG fusion transcript (EF194202.1) in prostate tumor samples as adenocarcinoma (the frequency was $56.8 \%$ ) with different Gleason score andя some paired normal prostate tissues as adenoma samples in our group of Ukrainian population. The obtained results show that the TMPRSS2$E R G$ fusion transcript is present at early stages of cancer development. In the further studies
\end{abstract}

(C) 2017 L. V. Mevs et al.; Published by the Institute of Molecular Biology and Genetics, NAS of Ukraine on behalf of Biopolymers and Cell. This is an Open Access article distributed under the terms of the Creative Commons Attribution License (http://creativecommons.org/licenses/by/4.0/), which permits unrestricted reuse, distribution, and reproduction in any medium, provided the original work is properly cited 
we plan to test whether the TMPRSS2-ERG fusion transcript can be used as a diagnostic marker of prostate cancer development.

Ke y w or d s: prostate cancer, fusion transcripts, relative gene expression

\section{Introduction}

Gene fusions, which involve the ETS family of transcription factors (ERG, ETV1, ETV4, ETV5) are a frequent event in prostate cancer [1]. Usually their 5' fusion partners are androgenregulated genes, particulary $T M P R S S 2, K L K 2$, CANT1, SLC45A3 and NDRG1. The most common of them is the TMPRSS2 gene. Because of their expression under the TMPRSS2 promoter the fusion transcripts were demonstrated to be up-regulated by androgenic hormones in the androgen-dependent prostate cancer tissue [2]. Transcription factors from the ETS family activate the oncogenic transcriptional programs, such as invasion, induction of DNA breaks and enhance the ETS oncogenic functions [3]. The ETS proteins are involved in the signaling pathways associated with cancer development $[3,4]$. It was also found that some members of this family can form the fusion transcripts, which may produce functional fusion proteins and proteins of the 3'-partner genes $[3,5]$. These fusion transcripts can be potentially formed as a result of deletions and translocations $[6,7]$. Although the mechanism of their formation has not been established yet, there is the evidence that noncoding RNAs, hormone levels, genotoxic stress and other factors play an important role in this process [8]. It has been shown that different exons and introns of both genes could be involved in the formation of their fusion transcripts in prostate cancer. That is why they usually have several isoforms $[2,4,5,9,10]$.
It was shown that specific fusion transcripts are detected with different frequency within populations of USA [1, 2, 8-10], Germany [2], Slovenian [11], Sweden [12] and Asia [13], but the frequency of detection of those transcripts for Ukrainian population has not been investigated yet. Therefore, it is important to determine what kind of these fusion transcripts is able to be expressed in tissues of the prostate cancer patients in Ukrainian population. The aim of this study was to detect several types of the fusion transcripts in Ukrainian population and to analyze possible relationships between the ETS fusion transcripts and the clinical characteristics of prostate cancer.

\section{Materials and Methods}

Sample collection. Prostate cancer samples and paired conventionally normal prostate tissues samples from opposite to cancer zone were collected from patients in National Cancer Institute (Kiev, Ukraine) and prostate adenoma samples were collected in Institute of Urology (Kiev, Ukraine) after radical prostatectomy. All samples were immediately frozen in liquid nitrogen. All patients gave written informed consent. The samples were collected in accordance with the Declaration of Helsinki and the guidelines issued by the Ethic Committee of the Institute of Urology and National Cancer Institute, National Academy of Medical Sciences of Ukraine. There were 20 samples of prostate adenoma (Institute of Urology, Kiev, Ukraine), 37 normal prostate tissue samples and 37 prostate carcinoma samples: 20 of 
prostate carcinoma with Gleason score $\leq 7$, and 17 of prostate aggressive carcinoma with Gleason score $>7$.

Total RNA isolation, cDNA synthesis. Total RNA extraction was done with RNeasy Mini kit (Qiagen, Germany) according to the manufacturer's recommendations after preparation of sample prouder in liquid nitrogen. Total RNA samples quality was determined in $1 \%$ agarose gel by band intensity of $28 \mathrm{~S}$ vs $18 \mathrm{~S}$ rRNA (28S/18S ratio) and spectrophotometrically (ratios of $260 \mathrm{~nm}$ vs $230 \mathrm{~nm}$ and $280 \mathrm{~nm}$ respectively). Concentration of total RNA was monitored with absorbance spectra at $260 \mathrm{~nm}$ (NanoDrop Technologies Inc. USA). The RNase free DNaseI treatment of total RNA was used to clean samples from genomic DNA. cDNA was synthesized from $1 \mu \mathrm{g}$ of total RNA using RevertAid H Minus M-MuLV Reverse Transcriptase (Thermo Fisher Scientific, USA) according to the manufacturer's protocol.

Quantitative PCR was performed using Maxima SYBR Green Master mix (Thermo Fisher Scientific, USA) on CFX96 Touch
(BIO-RAD, USA) under the conditions: $95^{\circ} \mathrm{C}-10 \mathrm{~min}$, following 40 cycles of $95^{\circ} \mathrm{C}$ $15 \mathrm{~s}, 60{ }^{\circ} \mathrm{C}-30 \mathrm{~s}$, elongation $72{ }^{\circ} \mathrm{C}-30 \mathrm{~s}$. Primers for qPCR were designed by Primer3 software (http://bioinfo.ut.ee/primer3-0.4.0) and BLAST (https://www.ncbi.nlm.nih.gov/ tools/primer-blast/) (Table 1).

The reference genes TBP, HPRT, ALAST1 and $K$-ALPHA- 1 were used for the gene expression normalization [14], the model for expression calculation was Livak $2^{-\Delta \mathrm{Ct}}$ and $2^{-\Delta \Delta \mathrm{Ct}}$ method- based relative quantities from the uploaded raw threshold cycle data [15].

Statistical analysis. The KolmogorovSmirnov and Lilliefors tests were used for assessing normality of distribution. KruskalWallis test was used to determine differences in multiple comparison between groups. MannWhitney test was used for assessment of differences for the expression of TMPRSS2-ERG fusion in groups with various stages, Gleason scores and levels of the prostate specific antigen. Spearman rank test was used to analyze associations between the expression of

Table 1. Sequences of primers for detection of selected fusion transcripts

\begin{tabular}{|c|c|c|c|}
\hline Fusion transcript & Primer name & Sequence & Amplicon length, bp \\
\hline $\begin{array}{l}\text { TMPRSS2-ERG } \\
\text { (EF194202.1) }\end{array}$ & $\begin{array}{l}\text { T/ERG_F } \\
\text { T/ERG_R }\end{array}$ & $\begin{array}{l}\text { GAGACCCATCTGGACTACCAA } \\
\text { TGTCCATAGTCGCTGGAGGA }\end{array}$ & 167 \\
\hline $\begin{array}{l}\text { TMPRSS2-ETV1a } \\
\text { (DQ204770.1) }\end{array}$ & $\begin{array}{l}\text { T/ETV1a_F } \\
\text { T/ETV1a_R }\end{array}$ & $\begin{array}{l}\text { TAGGCGCGAGCTAAGCAGGA } \\
\text { TTCAGCCTGATAGTCTGGTACA }\end{array}$ & 125 \\
\hline $\begin{array}{l}\text { TMPRSS2-ETV1b } \\
\text { (DQ204771.1) }\end{array}$ & $\begin{array}{l}\text { T/ETV1b_F } \\
\text { T/ETV1b_R }\end{array}$ & $\begin{array}{l}\text { ACCTATCATTACTCGATGCTGTTG } \\
\text { TTCAGCCTGATAGTCTGGTACA }\end{array}$ & 100 \\
\hline $\begin{array}{l}\text { TMPRSS2-ETV4a } \\
\text { (DQ396625) }\end{array}$ & $\begin{array}{l}\text { T/ETV4a_F } \\
\text { T/ETV4a_R }\end{array}$ & $\begin{array}{l}\text { AGTTTGTAAGAGGAGCCTCAGCATC } \\
\text { AGCCACGTCTCCTGGAAGTGACTTA }\end{array}$ & 189 \\
\hline $\begin{array}{l}\text { TMPRSS2-ETV5b } \\
\text { (EU314930) }\end{array}$ & $\begin{array}{l}\text { T/ETV5b_F } \\
\text { T/ETV5b_R }\end{array}$ & $\begin{array}{l}\text { AGGCTTCCAACCCCGTCGTC } \\
\text { CTTGCTGATCATAAAACCCGTCC }\end{array}$ & 162 \\
\hline $\begin{array}{l}\text { TMPRSS2-ETV5c } \\
\text { (EU314931) }\end{array}$ & $\begin{array}{l}\text { T/ETV5c_F } \\
\text { T/ETV5c_R }\end{array}$ & $\begin{array}{l}\text { GAAAACCCCTATCCCGCACA } \\
\text { TAAAACCCGTCCATGGTGCT }\end{array}$ & 260 \\
\hline
\end{tabular}


TMPRSS2-ERG fusion and clinical data of patients. p-values $>0.05$ were considered as statistically insignificant [16]. All statistical procedures were performed, using the STATISTICA 10.0 software (StatSoft, USA).

\section{Results and Discussion}

It is known that fusion transcripts can be formed by the TMPRSS 2 gene and the ETS family members in prostate cancer [2] and expression of some fusion transcripts may correlate with the clinical data [11]. The gene fusion products are involved in the regulation of cell cycle, prostate cancer initiation, progression and invasive potential of cells [4, 17]. Thus, we decided to detect their expression in Ukrainian population and to test whether they can be used as markers of the development and progression of prostate cancer.

We studied expression of 6 fusion transcripts: TMPRSS2-ERG, TMPRSS2-ETV1a, TMPRSS2ETV1b, TMPRSS2-ETV4a, TMPRSS2-ETV5b, TMPRSS2-ETV5c (Fig.1) in prostate cancer samples (Table 2). These gene fusions typically result in the fusion of the 5'-part of androgen-regulated genes to the oncogenic ETS family genes, causing their over-expression [17]. Taken TMPRSS2-ERG is namely TMPRSS2ERG, isoform 2 (EF194202.1), which was detected with a high frequency in the study of Lapointe J. et al. [12].

Bioinformatic analysis using ORF finder (https://www.ncbi.nlm.nih.gov/orffinder/) and BLASTP https://blast.ncbi.nlm.nih.gov/Blast. cgi) has shown that some fusion transcripts can produce proteins: TMPRSS2-ERG potentially can produce the ERG protein, TMPRSS2ETV4a - ETV4 protein; some of them may even be able to produce fusion proteins (e,g, TMPRSS2-ETV5 fusion transcripts). Our data did not show the existence of any proteins from the TMPRSS2-ETV1a and TMPRSS2$E T V 1 b$ fusion transcripts, but an experimental study indicated that TMPRSS2-ETVIa can produce the ETV1 protein [3].

Our study of 6 fusion transcripts in 37 prostate carcinoma samples allowed us to detect only one fusion transcript - TMPRSS2-ERG (Table 2). This transcript was extracted from agarose gel, cleaned by GeneJET Extraction Kit (Thermo Scientific) and sequenced. The presence of the expected fusion transcript in prostate cancer samples was confirmed (Fig. 2).

In our study this fusion transcript was detected in 21 out of 37 prostate cancer samples, i.e. with a frequency of $56.8 \%$, confirming the frequency of its detection in other studies (40$80 \%)[1,2,4]$.

The androgen signaling has been shown to induce the proximity of TMPRSS 2 and ERG locus in androgen responsive cells, and in combination with agents causing DNA double strand breaks induces the TMPRSS2-ERG gene fusions $[8,19,20]$. So the level of androgens in the body plays an important role in the expression of fusion transcripts formed with the TMPRSS2 gene. Also the TMPRSS2-ERG fusion transcript product binds to the $E R G$ locus and drives the over-expression of wild-type $E R G$ in prostate cancers [18]. Moreover, androgen signaling-mediated up-regulation of TMPRSS2-ERG resulted in the concomitant up-regulation of the wild-type $E R G$ transcription in VCaP cells. The loss of wild-type $E R G$ expression was associated with a decrease in their invasive potential [18].

The expression of other fusion transcripts was not detected. Notably, their expression 
depends on many factors, including features transcripts were detected in the highest freof prostate carcinogenesis and studied popu- quency in heterogeneous American populalations. For instance, the TMPRSS2-ETV1, tions by Tomlins S. et al. [2,9] and HelgeTMPRSS2-ETV4 and TMPRSS2-ETV5 fusion son B. et al. [10], but these three fusion tran-
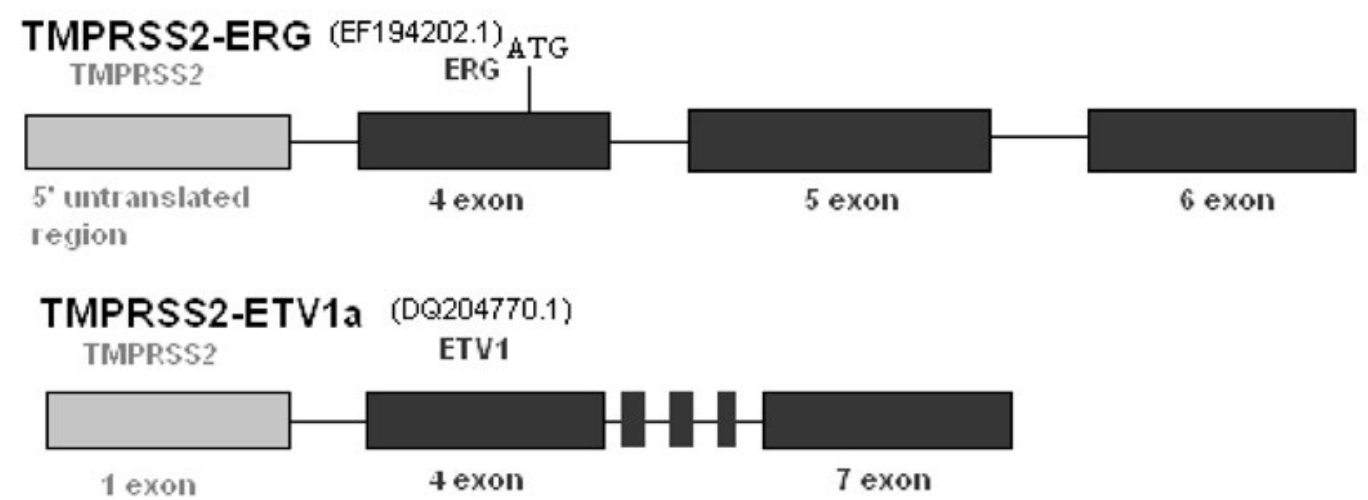

TMPRSS2-ETV1b (DQ204771.1)

TIMIPRSS2

ETV1
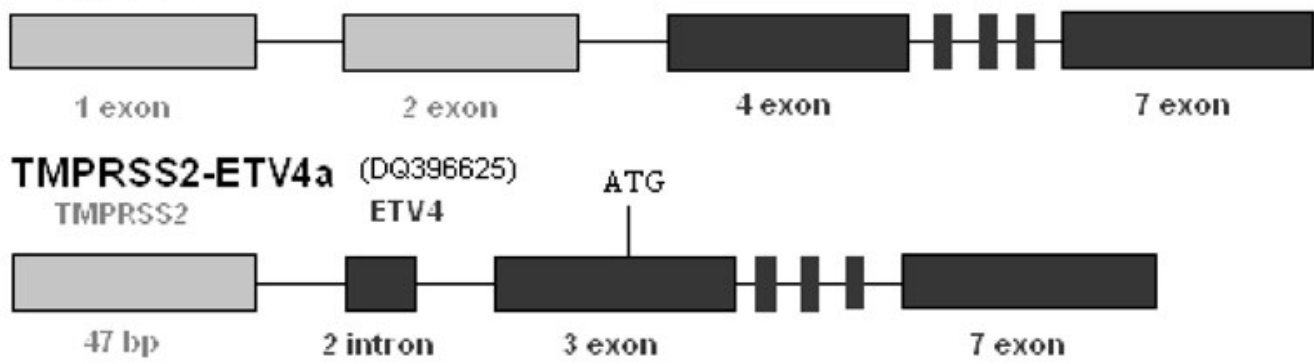

TMPRSS2-ETV5b (EU314930) ${ }_{\text {ATG }}$

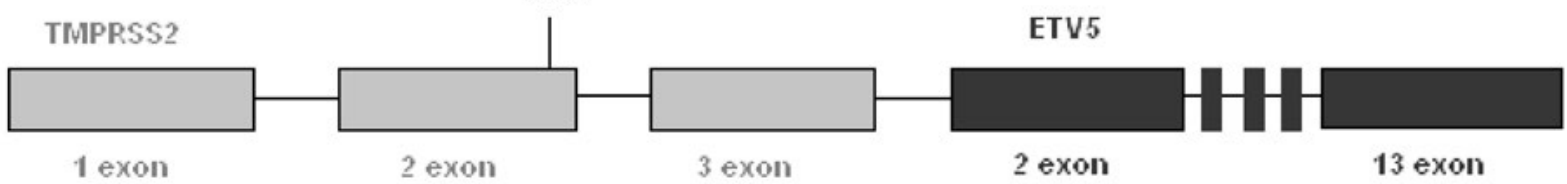

TMPRSS2-ETV5c (EU314931)

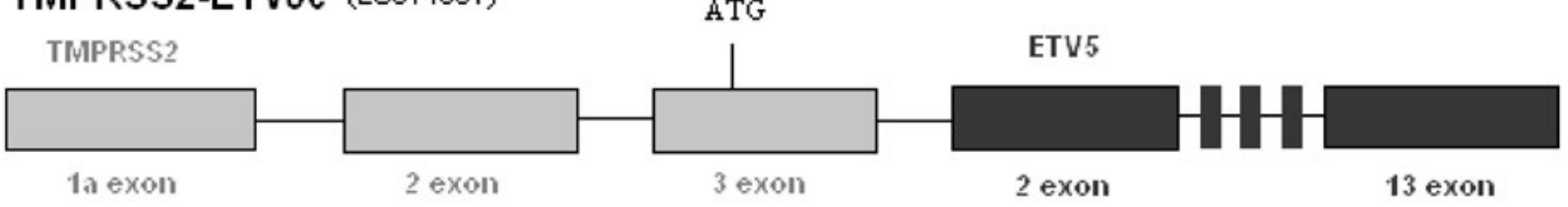

Fig. 1. Schematic representation of the fusion transcripts used in the study.

Note: ATG - start codon for protein. 
Detection of prostate specific ETS fusion transcripts in cancer samples

Table 2. Fusion transcripts and clinical characteristics of prostate cancer samples.

\begin{tabular}{|c|c|c|c|c|c|c|c|c|c|c|}
\hline \multirow{2}{*}{$\begin{array}{l}\text { ㄹ. } \\
\text { : } \\
\text { : }\end{array}$} & \multicolumn{6}{|c|}{ Fusion transcripts } & \multicolumn{4}{|c|}{ Clinical characteristics } \\
\hline & $\begin{array}{c}\text { TMPRSS2- } \\
E R G\end{array}$ & $\begin{array}{l}\text { TMPRSS2- } \\
\text { ETV1a }\end{array}$ & $\begin{array}{c}\text { TMPRSS2- } \\
\text { ETV1b }\end{array}$ & $\begin{array}{c}\text { TMPRSS2- } \\
\text { ETV } 4 a\end{array}$ & $\begin{array}{c}\text { TMPRSS2- } \\
\text { ETV } 5 b\end{array}$ & $\begin{array}{c}\text { TMPRSS2- } \\
\text { ETV5c }\end{array}$ & Stage & $\begin{array}{c}\text { Gleason } \\
\text { score }\end{array}$ & TNM & $\begin{array}{c}\mathrm{PSA} \\
\mathrm{ng} / \mathrm{ml}\end{array}$ \\
\hline $1 \mathrm{~T}$ & - & - & - & - & - & - & II & \multirow{11}{*}{$<7$} & T2cNxM0 & 27,3 \\
\hline $2 \mathrm{~T}$ & - & - & - & - & - & - & II & & T2cNxM0 & 25,2 \\
\hline $3 \mathrm{~T}$ & + & - & - & - & - & - & II & & T2pN0M0 & 5,03 \\
\hline $4 \mathrm{~T}$ & + & - & - & - & - & - & II & & T2cN0M0 & 29,08 \\
\hline $5 \mathrm{~T}$ & - & - & - & - & - & - & II & & T2bNxM0 & 6,5 \\
\hline $6 \mathrm{~T}$ & + & - & - & - & - & - & II & & T2bN0M0 & 12,8 \\
\hline $7 \mathrm{~T}$ & + & - & - & - & - & - & II & & T2aN0M0 & 9,3 \\
\hline $8 \mathrm{~T}$ & + & - & - & - & - & - & II & & T2aNxM0 & 18,6 \\
\hline 9T & + & - & - & - & - & - & II & & T2aN0M0 & 13,3 \\
\hline $10 \mathrm{~T}$ & - & - & - & - & - & - & II & & T2aN0M0 & 6,04 \\
\hline $11 \mathrm{~T}$ & - & - & - & - & - & - & III & & T3bNxM0 & 23,57 \\
\hline $12 \mathrm{~T}$ & + & - & - & - & - & - & $\mathrm{I}$ & \multirow{9}{*}{7} & T1cNxM0 & 8,19 \\
\hline $13 \mathrm{~T}$ & + & - & - & - & - & - & II & & T2cNxM0 & 19,27 \\
\hline $14 \mathrm{~T}$ & - & - & - & - & - & - & II & & T2cNxM0 & 19,8 \\
\hline $15 \mathrm{~T}$ & - & - & - & - & - & - & II & & T2aNxM0 & 11,7 \\
\hline $16 \mathrm{~T}$ & - & - & - & - & - & - & II & & T2cNxM0 & 13,9 \\
\hline $17 \mathrm{~T}$ & + & - & - & - & - & - & II & & T2aNxM0 & 7,13 \\
\hline $18 \mathrm{~T}$ & + & - & - & - & - & - & II & & T2aNxM0 & 5,6 \\
\hline $19 \mathrm{~T}$ & + & - & - & - & - & - & II & & T2cN0M0 & 14,3 \\
\hline $20 \mathrm{~T}$ & + & - & - & - & - & - & III & & T2bN0M0 & 24,6 \\
\hline $21 \mathrm{~T}$ & + & - & - & - & - & - & III & \multirow{17}{*}{$>7$} & T3bN0M0 & 12,12 \\
\hline $22 \mathrm{~T}$ & - & - & - & - & - & - & II & & T2bNxM0 & 6,92 \\
\hline $23 \mathrm{~T}$ & + & - & - & - & - & - & III & & T3bNxM0 & 20,9 \\
\hline $24 \mathrm{~T}$ & + & - & - & - & - & - & III & & T3bN0M0 & 84,2 \\
\hline $25 \mathrm{~T}$ & - & - & - & - & - & - & III & & T3bNxM0 & 51 \\
\hline $26 \mathrm{~T}$ & + & - & - & - & - & - & II & & T2bNxM0 & 33 \\
\hline $27 \mathrm{~T}$ & - & - & - & - & - & - & III & & T2bNxM0 & 0,48 \\
\hline $28 \mathrm{~T}$ & - & - & - & - & - & - & IV & & T3aN0M1 & 37,8 \\
\hline $29 \mathrm{~T}$ & + & - & - & - & - & - & III & & T3bNxM0 & 106 \\
\hline $30 \mathrm{~T}$ & + & - & - & - & - & - & IV & & T2cN1M0 & 17 \\
\hline $31 \mathrm{~T}$ & + & - & - & - & - & - & III & & T3aN0M0 & 25,08 \\
\hline $32 \mathrm{~T}$ & - & - & - & - & - & - & II & & T2bN0M0 & 20,29 \\
\hline $33 \mathrm{~T}$ & - & - & - & - & - & - & IV & & T2cN0M1 & 22,6 \\
\hline $34 \mathrm{~T}$ & + & - & - & - & - & - & III & & T3bNxM0 & 16 \\
\hline $35 \mathrm{~T}$ & - & - & - & - & - & - & III & & T3bNxM0 & 86,26 \\
\hline $36 \mathrm{~T}$ & + & - & - & - & - & - & III & & T2cN1M0 & 2,27 \\
\hline $37 \mathrm{~T}$ & - & - & - & - & - & - & II & & T2cN0M0 & 9,68 \\
\hline
\end{tabular}

Notes: "+" - detected fusion transcript; "-“" - no expression of fusion transcript. 


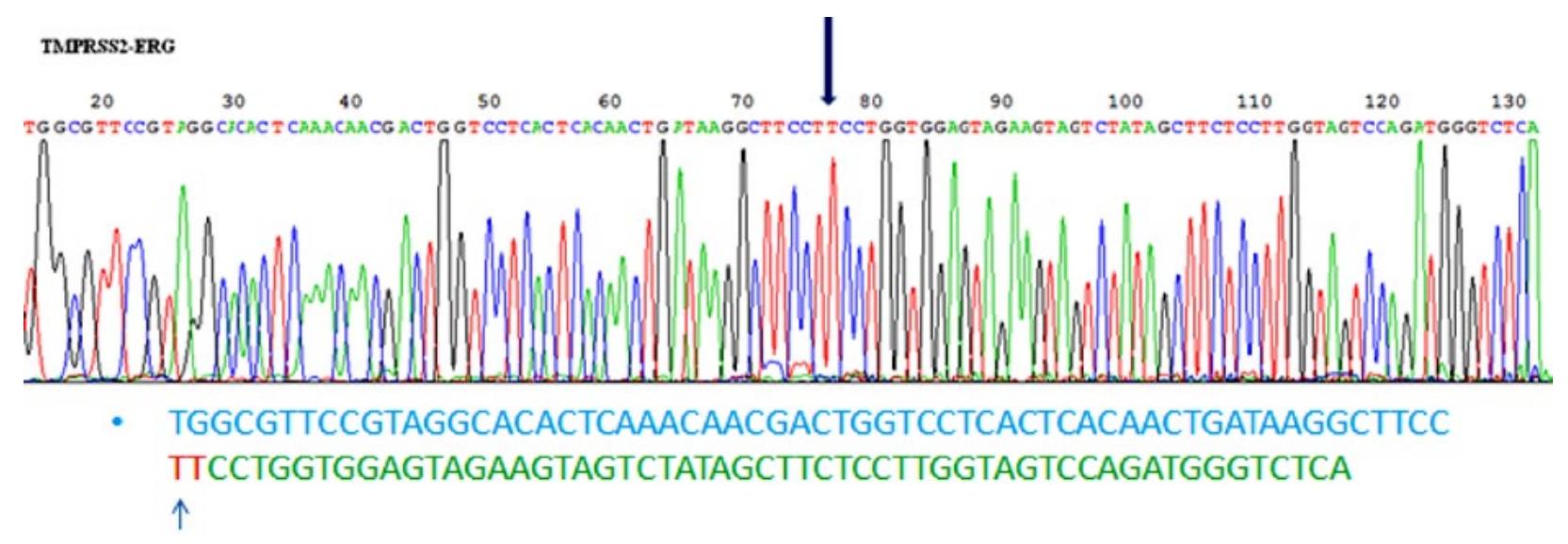

place of the junction

Fig. 2. Chromatogram (sequence example) of the TMPRSS2-ERG fusion transcript (Note: transcript junction marked by arrows).

\section{$\lg 2^{-\Delta \Delta C t}$}

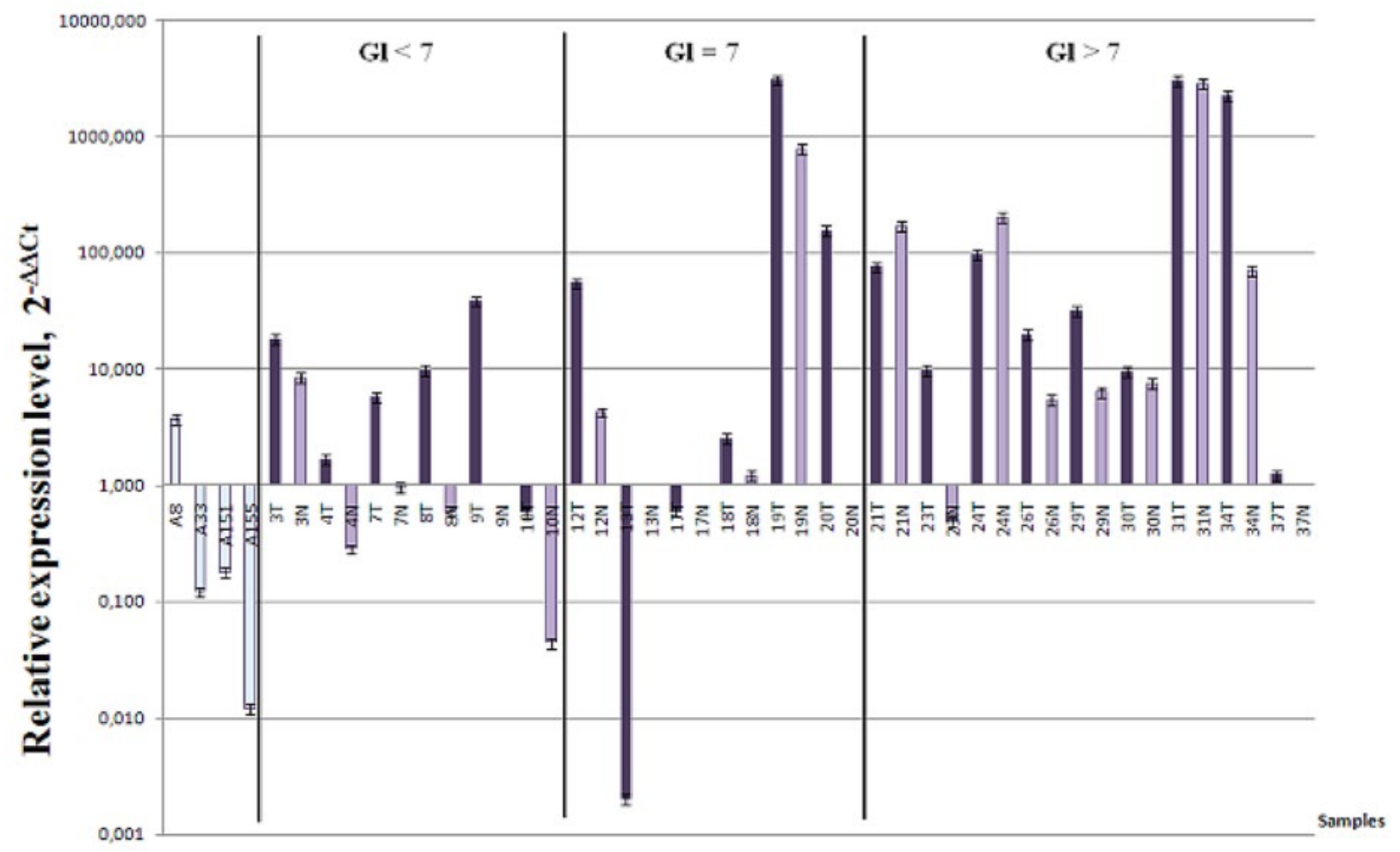

Fig. 3. Relative gene expression of TMPRSS2-ERG fusion transcript in prostate cancer samples.

Note: Gl - Gleason score, $A$-adenoma samples, $T$-prostate adenocarcinoma samples, $N$-paired normal prostate tissues. 
scripts were not detected in the study of Dong J. et al. in Eastern Chinese population [13]. They usually have a low frequency (1-10\%), so their detection requires a large number of samples.

We studied whether an expression frequency of the] TMPRSS2-ERG fusion transcript is associated with the clinical characteristics (stages, Gleason scores and levels of the PSA) of prostate cancer patients though no such correlation was found. We observed approximately the same expression frequency of TMPRSS2$E R G$ in all prostate adenocarcinoma samples of different stages and three groups of Glisone score. So, there is the hypothesis that these changes can occur at an earlier stage and proceed at all stages of the tumor development and growth. There is evidence that the expression of the fusion transcripts can be observed at the earliest stages of cancer [2]. It is most likely that the emergence of the fusion transcript is typical for a specific mechanism of oncogenic transformation. That is why we investigated the expression of the detected fusion transcript in paired conventionally normal tissue samples and adenomas. $2^{\text {-ddCt }}$ model was used for calculation of the TMPRSS2-ERG relative gene expression, normalized to the mean of the adenomas group. The levels of relative TMPRSS2-ERG expression in three types of prostate tissues are shown in Fig. 3.

As previously reported, this fusion transcript was detected in 21 samples of prostate cancer. The expression of TMPRSS2-ERG was detected in 16 normal prostate tissue samples and 4 samples of prostate adenoma. The fusion transcript, detected in these samples, was sequenced, and the TMPRSS2-ERG fusion transcript was confirmed (Fig. 2).
Kruskal-Waillis test determined differences in the TMPRSS2-ERG relative expression levels among investigated groups with $\mathrm{p}=0.001$. All fusion positive samples were distributed into 7 groups: 3 adenocarcinoma groups with Gleason score $<7,=7,>7$ and 3 respective groups of normal tissues divided by Gleason score $<7$, $=7,>7$, and the adenoma samples group. Mann-Witney test has shown significant differences between 9 pairs of investigated groups. All 3 groups of prostate adenocarcinoma with 3 types of Gleason score $(<7,=7,>7)$ and one group of normal tissue with Gleason score $>7$ demonstrated a significant increase in the $T M P R S S 2-E R G$ relative expression levels compared with the adenoma group $(\mathrm{p}=0.04$; $\mathrm{p}=0.04 ; \mathrm{p}=0.01 ; \mathrm{p}=0.012$ respectively). Among paired groups of prostate adenocarcinoma and normal tissue with the same Gleason score the only significant differences were detected between adenocarcinoma and normal tissue with Gleason score $<7(\mathrm{p}=0.045)$. Two other prostate adenocarcinoma groups with Gleason score $=7$ and Gleason score $>7$ had significant differences (increased relative expression levels) with normal tissue Gleason score $<7(\mathrm{p}=0.025 ; \mathrm{p}=0.003$ respectively). Furthermore, we found the evidence of significant increase in the TMPRSS2-ERG relative expression level in the prostate adenocarcinoma groups with Gleason score $>7$ compared to normal tissue with Gleason score $=7(p=0.03)$. Among groups of normal tissue with different Gleason score significant differences between Gleason score $<7$ and Gleason score $>7$ $(p=0.08)$ were detected. No differences were detected between the prostate adenocarcinoma groups with different Gleason score. The Benjamini-Hochberg procedure with false dis- 
covery rate 0.10 was used to correct $p$ value under multiple comparison detection [21]. All our data with $\mathrm{p}$ value $(\mathrm{p}<0.05)$ were detected as significant in this procedure with 0.1 false discovery rate.

In 21 samples of fusion positive prostate adenocarcinoma samples we detected 16 paired fusion positive normal samples. Those were not false positive results, because all TMPRSS2$E R G$ transcripts from normal samples were sequenced. This is consistent with the notion that some fusion transcripts can be detected in normal prostate tissue [3]. This may mean that there are tumor cells in normal tissue, or the normal tissue has already undergone oncogenic changes and is no more the normal one. Besides, the fusion transcripts are already found in the adenomas (4 fusion positive specimens in the prostate adenomas of 20 samples).

Our results have shown that the TMPRSS2$E R G$ fusion transcript is present at early stages of the cancer development and its expression level significantly increases in a high Gleason score group.

It was detected that the TMPRSS2-ERG fusion transcript has an oncogenic effect on the development of prostate cancer, since it can potentially produce the oncogenic ERG protein [3]. It is well known that ERG is involved in the Wnt signaling pathway, which regulates gene transcription, cell proliferation and cell migration [4]. There is evidence that one of its isoforms is capable of production of a chimeric protein that is able to regulate the activity of the insulin-like growth factor-1 receptor (IGF1R). It plays a key role in cell growth and tumorigenesis, and is overexpressed in most malignancies, including prostate cancer, and the IGF1 signaling pathway, an important cell survival network. Transactivation of the IGFIR gene by oncogene ERG constitutes a key event in the prostate cancer development. Enhanced activation of the overexpressed IGF1R by locally produced or circulating IGF1 or IGF2 may provide a selective advantage to tumor cells [20].

Additionally, our data suggest the formation of this transcript at the early stages of carcinogenesis of the prostate. In future it can be used in the development of a method for early diagnosis and prognosis of the course of the disease, taking into account the data obtained in other studies $[11,22]$.

The recent studies demonstrate the connection between androgen receptor expression and expression of the TMPRSS2-ERG fusion in prostate cancer, giving arguments in favor of the fact that the expression of this fusion transcript depends on the influence of androgens in hormone-dependent tumors [4, 23, 24]. It is also known that the expression of TMPRSS2-ERG fusion cooperates with such signaling pathways as RAS/RAF and PI3K/PTEN/AKT [24]. Krstanoski Z. et al. tested association between the TMPRSS2-ERG fusion transcript by FISH method and several clinicopathological variables, i.e., pT stage (describes the size of the primary tumour), extended lymph node dissection status, and Gleason score, correcting for multiple comparisons. Only the association with pT stage was significant $(p=0.05)$ [16].

Because the credible mechanisms of formation of fusion transcripts are still unknown, our objective for further research is to reveal the mechanism of their formation in the patients with prostate cancer, as well as the mechanisms by which fusion transcripts affect the development of prostate cancer disease. 


\section{Conclusions}

Among 6 investigated fusion transcripts (TMPRSS2-ERG, TMPRSS2-ETV1a, TMPRSS2ETV1b, TMPRSS2-ETV4a, TMPRSS2-ETV5b, TMPRSS2-ETV5C) only the TMPRSS2-ERG fusion transcript was detected. Subsequent sequencing confirmed the presence of TMPRSS2$E R G$ fusion transcript. Its frequency in prostate tumors was determined to be $56.8 \%$ in our group. Additionally, we observed the expression of TMPRSS2-ERG in 16 normal prostate tissue samples $(43.2 \%)$ and 4 samples of prostate adenoma samples (20\%). It suggests that the frequency of TMPRSS2-ERG fusion transcript would be rather the same as in other European populations and higher than in Asian populations. The obtained results show that the fusion transcript TMPRSS2-ERG is present at the early stages of cancer.

Whereas the ETS fusions were discovered several years ago, and are important in several aspects of the prostate cancer initiation and progression, the formation of TMPRSS2$E R G$ fusion is still under investigation [4]. Thus, in our further studies we intend to identify the mutation which could form the TMPRSS2-ERG fusion transcript and test whether it can be used as a diagnostic marker of the formation and development of prostate cancer, in investigation of the fusion positive tumors carcinogenic features.

\section{REFERENCES}

1. Kumar-Sinha C, Tomlins SA, Chinnaiyan AM. Recurrent gene fusions in prostate cancer. Nat Rev Cancer. 2008;8(7):497-511.

2. Lin C, Yang L, Tanasa B, Hutt K, Ju BG, Ohgi K, Zhang J, Rose DW, Fu XD, Glass CK, Rosenfeld $M G$. Nuclear receptor-induced chromosomal proximity and DNA breaks underlie specific translocations in cancer. Cell. 2009;139(6):1069-83.

3. Luo JH, Liu S, Zuo ZH, Chen R, Tseng GC, Yu YP. Discovery and classification of fusion transcripts in prostate cancer and normal prostate tissue. $\mathrm{Am} \mathrm{J}$ Pathol. 2015;185(7):1834-45.

4. Feng FY, Brenner JC, Hussain M, Chinnaiyan AM. Molecular pathways: targeting ETS gene fusions in cancer. Clin Cancer Res. 2014;20(17):4442-8.

5. Clark J, Merson S, Jhavar S, Flohr P, Edwards S, Foster CS, Eeles R, Martin FL, Phillips DH, Crundwell M, Christmas T, Thompson A, Fisher C, Kovacs G, Cooper CS. Diversity of TMPRSS2-ERG fusion transcripts in the human prostate. Oncogene. 2007;26(18):2667-73.

6. Tomlins $S$ et al. Recurrent gene fusions in prostate cancer. United States Patent. 2013; 13: 1-218.

7. Shtivelman E, Beer TM, Evans CP. Molecular pathways and targets in prostate cancer. Oncotarget. 2014;5(17):7217-59.

8. Tomlins $S A$, Rhodes DR, Perner S, Dhanasekaran SM, Mehra R, Sun XW, Varambally S, Cao X, Tchinda J, Kuefer R, Lee C, Montie JE, Shah RB, Pienta KJ, Rubin MA, Chinnaiyan AM. Recurrent fusion of TMPRSS2 and ETS transcription factor genes in prostate cancer. Science. 2005;310(5748):644-8.

9. Tomlins SA, Mehra R, Rhodes DR, Smith LR, Roulston D, Helgeson BE, Cao X, Wei JT, Rubin MA, Shah RB, Chinnaiyan AM. TMPRSS2:ETV4 gene fusions define a third molecular subtype of prostate cancer. Cancer Res. 2006;66(7):3396-400.

10. Helgeson BE, Tomlins SA, Shah N, Laxman B, Cao Q, Prensner JR, Cao X, Singla N, Montie JE, Varambally $S$, Mehra R, Chinnaiyan AM. Characterization of TMPRSS2:ETV5 and SLC45A3:ETV5 gene fusions in prostate cancer. Cancer Res. 2008;68(1):73-80.

11. Krstanoski Z, Vokac NK, Zagorac A, Pospihalj B, Munda M, Dzeroski S, Golouh R. TMPRSS2:ERG gene aberrations may provide insight into $\mathrm{pT}$ stage in prostate cancer. BMC Urol. 2016;16(1):35.

12. Lapointe J, Kim YH, Miller MA, Li C, Kaygusuz G, van de Rijn M, Huntsman DG, Brooks JD, Pollack JR. A variant TMPRSS2 isoform and ERG fusion product in prostate cancer with implications 
for molecular diagnosis. Mod Pathol. 2007;20(4): 467-73.

13. Dong J, Xiao L, Sheng L, Xu J, Sun ZQ. TMPRSS2:ETS fusions and clinicopathologic characteristics of prostate cancer patients from Eastern China. Asian Pac J Cancer Prev. 2014;15(7):3099-103.

14. Schmidt U, Fuessel $S$, Koch $R$, Baretton GB, Lohse A, Tomasetti S, Unversucht S, Froehner M, Wirth MP, Meye A. Quantitative multi-gene expression profiling of primary prostate cancer. Prostate. 2006;66(14):1521-34.

15. Livak KJ, Schmittgen TD. Analysis of relative gene expression data using real-time quantitative PCR and the 2(-Delta Delta C(T)) Method. Methods. 2001;25(4):402-8.

16. Kochetov AG, Lyang OV, Masenko VP, Zhirov IV, Nakonechnikov SN, Tereshchenko SN. Metody statisticheskoy obrabotki meditsinskikh dannykh: Metodicheskiye rekomendatsii dlya ordinatorov i aspirantov meditsinskikh uchebnykh zavedeniy, nauchnykh rabotnikov. Moskva. 2012; 12.

17. Mani RS, Iyer MK, Cao Q, Brenner JC, Wang L, Ghosh A, Cao X, Lonigro RJ, Tomlins SA, Varambally $S$, Chinnaiyan AM. TMPRSS2-ERG-mediated feed-forward regulation of wild-type ERG in human prostate cancers. Cancer Res. 2011;71(16):5387-92

18. Mani RS, Tomlins SA, Callahan K, Ghosh A, Nyati $M K$, Varambally $S$, Palanisamy $N$, Chinnaiyan AM. Induced chromosomal proximity and gene fusions in prostate cancer. Science. 2009;326(5957):1230.

19. Haffner MC, Aryee MJ, Toubaji A, Esopi DM, Albadine R, Gurel B, Isaacs WB, Bova GS, Liu W, Xu J, Meeker AK, Netto G, De Marzo AM, Nelson WG, Yegnasubramanian $S$. Androgen-induced TOP2Bmediated double-strand breaks and prostate cancer gene rearrangements. Nat Genet. 2010;42(8):668-75

20. Meisel Sharon S, Pozniak Y, Geiger T, Werner H. TMPRSS2-ERG fusion protein regulates insulin-like growth factor-1 receptor (IGF1R) gene expression in prostate cancer: involvement of transcription factor Sp1. Oncotarget. 2016;7(32):51375-51392. Central

21. Benjamini Y, Hochberg Y. Controlling the false discovery rate: a practical and powerful approach to multiple testing. J R Stat Soc Series B Stat Methodol. 1995, 57(1): 289-300.
22. Baker SJ, Reddy EP. Understanding the temporal sequence of genetic events that lead to prostate cancer progression and metastasis. Proc Natl Acad Sci U S A. 2013;110(37):14819-20.

23. Carver BS, Chapinski C, Wongvipat J, Hieronymus H, Chen Y, Chandarlapaty S, Arora VK, Le C, Koutcher J, Scher H, Scardino PT, Rosen N, Sawyers $C L$. Reciprocal feedback regulation of PI3K and androgen receptor signaling in PTEN-deficient prostate cancer. Cancer Cell. 2011;19(5):575-86.

24. Han B, Mehra R, Lonigro RJ, Wang L, Suleman K, Menon A, Palanisamy N, Tomlins SA, Chinnaiyan $A M$, Shah $R B$. Fluorescence in situ hybridization study shows association of PTEN deletion with ERG rearrangement during prostate cancer progression. Mod Pathol. 2009;22(8):1083-93.

\section{Виявлення простат специфічних злитих транскриптів ETS у зразках раку передміхурової залози}

Л. В. Мевс, Г. В. Геращенко, Е. Е. Розенберг, М. В. Пікуль, М. В. Мариніченко, О. П. Гризодуб, С. О. Возіанов, Е. А. Стаховський, В. І. Кашуба

Мета. Виявити типи злитих транскриптів в українській популяції та проаналізувати можливий зв>язок між наявністю злитих транскриптів ETS та клінічними характеристиками раку передміхурової залози. Методи. Кількісний ПЛР (q-PCR) використовували для аналізу експресії 6 злитих транскриптів на рівні мРНК. Ампліфіковані продукти перевіряли за допомогою гель-електрофорезу та секвенуванням. Нами було проаналізовано 37 свіжо заморожених зразків тканин раку передміхурової залози, 37 парних до них умовно нормальних зразків тканини передміхурової залози та 20 зразків аденоми. Результати. Нами було проаналізовано 6 злитих транскриптів ETS: злиття TMPRSS2 з ERG, ETV1, ETV4, ETV5. У вибірці із 37 пацієнтів з аденокарциномою передміхурової залози було виявлено лише один з шести злитих транскриптів. Частота детекції злитого транскрипту TMPRSS2-ERG в тканинах раку передміхурової залози становила 56,8 \%. Експресія TMPRSS2-ERG також була виявлена у 16 зразках умовно нормальних тканин передміхурової залози ( 43,2 \%) та у 4 зразках аденоми передміху- 
рової залози (20 \%). Не було виявлено кореляції між частотою TMPRSS2-ERG та клінічними характеристиками пухлин у зразках карцином. Проте аналіз відносної експресії генів у всіх досліджених групах показав змінену експресію TMPRSS2-ERG у деяких групах з різними показниками ступеня Глісона в зразках аденокарцином порівняно з аденомами та зразками умовно нормальних тканин. Найбільш висока експресія TMPRSS2-ERG була виявлена в групі аденокарцином передміхурової залози з оцінками ступеня Глісона $>$ 7. Висновки. У нашій досліджуваній групі населення України нами було детектовано злитий транскрипт TMPRSS2-ERG (EF194202.1) у пухлинних зразках передміхурової залози як аденокарцином (частота 56,8 \%) з різним ступенем Глісона та парним до них умовно нормальних тканинах передміхурової залози, так і в зразках аденом. Отримані результати показують, що злитий транскрипт TMPRSS2-ERG присутній вже на ранніх стадіях розвитку ракового захворювання. У подальших дослідженнях ми плануємо перевірити, чи може злитий транскрипт TMPRSS2-ERG бути використаний як діагностичний маркер утворення злитих транскриптів та можливого розвиток раку передміхурової залози.

К л юч о в і с л о в а: рак передміхурової залози, злиті транскрипти, відносна експресія генів.

\section{Выявление простат специфических слитых транскриптов ETS в образцах рака простаты}

Л. В. Мевс, В. Геращенко, Е. Е. Розенберг, М. В. Пикуль, М. В. Мариниченко,

А. П. Грызодуб, С. А. Возианов,

Е. А. Стаховський, В. И. Кашуба

Цель. Выявить типы слитых транскриптов в украинской популяции и проанализировать возможную связь между наличием слитых транскриптов ETS и клиническими характеристиками рака простаты. Методы. Количественный ПЦР (q-PCR) использовали для анализа экспрессии 6 слитых транскриптов на уровне мРНК. Амплифицированные продукты проверяли с помощью гель-электрофореза и секвенированием.
Нами были проанализированы 37 свежо замороженных образцов тканей рака простаты, 37 парных к ним условно нормальных образцов ткани простаты и 20 образцов аденомы. Результаты. Нами были проанализированы 6 слитых транскриптов ETS: слияние TMPRSS2 с ERG, ETV1, ETV4, ETV5. В выборке из 37 пациентов с аденокарциномой простаты было выявлено лишь один из шести слитых транскриптов. Частота детекции слитного транскрипта TMPRSS2$E R G$ в тканях рака простаты составляла $56,8 \%$. Экспрессия TMPRSS2-ERG также была обнаружена в 16 образцах условно нормальных тканей простаты $(43,2 \%)$ и в 4 образцах аденомы простаты (20\%). Не было обнаружено корреляции между частотой $T M P R S S 2-E R G$ и клиническими характеристиками опухолей в образцах карцином. Однако анализ относительной экспрессии генов во всех исследованных группах показал измененную экспрессию TMPRSS2$E R G$ в некоторых группах с различными показателями степени Глисона в образцах аденокарцином по сравнению с аденомы и образцами условно нормальных тканей. Наиболее высокая экспрессия TMPRSS2-ERG была обнаружена в группе аденокарцином простаты по оценкам степени Глисона $>7$. Выводы. В нашей исследуемой группе населения Украины нами было детектируемого слитый транскрипт TMPRSS2-ERG (EF194202.1) в опухолевых образцах простаты как аденокарцином (частота $56,8 \%$ ) с разной степенью Глисона и парным к ним условно нормальных тканях простаты, так и в образцах аденом. Полученные результаты показывают, что слитый транскрипт $T M P R S S 2-E R G$ присутствует уже на ранних стадиях развития ракового заболевания. В дальнейших исследованиях мы планируем проверить, может ли слитый транскрипт TMPRSS2-ERG быть использован как диагностический маркер образования слитых транскриптов и возможного развитие рака простаты.

Ключевы е слов а: рак простаты, слитые транскрипты, относительная экспрессия генов.

Received 02.06.2017 